\title{
Strategic Orientations, Dynamic Capabilities, and Firm Performance: an Analysis for Knowledge Intensive Business Services
}

\author{
Soumodip Sarkar ${ }^{1,2}$ - Dulce Matos Coelho ${ }^{1,3}$. \\ João Maroco ${ }^{4}$
}

Received: 18 August 2015 / Accepted: 4 October 2016 /

Published online: 25 October 2016

(C) Springer Science+Business Media New York 2016

\begin{abstract}
The strategic orientations of a firm are considered crucial for enhancing firm performance and their impact can be even greater when associated with dynamic capabilities, particularly in complex and dynamic environments. This study empirically analyzes the relationship between market, entrepreneurial and learning orientations, dynamic capabilities, and performance using an integrative approach hitherto little explored. Using a sample of 209 knowledge intensive business service firms, this paper applies structural equation modeling to explore both direct effects of strategic orientations and the mediating role of dynamic capabilities on performance. The study demonstrates that learning orientation and one of the dimensions of entrepreneurial orientation have a direct positive effect on performance. On the other hand, dynamic capabilities mediate the relationships between some of the strategic orientations and firm performance. Overall, when dynamic capabilities are combined with the appropriate strategic orientations, they enhance firm performance. This paper contributes to a better understanding of the knowledge economy, given the important role knowledge intensive business services play in such a dynamic and pivotal sector.
\end{abstract}

Soumodip Sarkar

ssarkar@uevora.pt

Dulce Matos Coelho

dulce.matos@esce.ips.pt

João Maroco

jpmaroco@ispa.pt

CEFAGE-UE, Évora, Portugal

2 Department of Management, University of Évora, Largo dos Colegiais, n 2, Évora, Portugal

3 Department of Economics and Management, ESCE-IPS, Setúbal, Portugal

4 Department of Psychological Sciences, ISPA-IU, Lisbon, Portugal

Springer 